\title{
A coerência interativa no discurso político de posse e sua didatização em sala de aula da Educação Básica
}

\section{Interactive coherence in political inaugural speech and its didacticism in Basic Education classrooms}

\author{
Eulália Vera Lúcia Fraga Leurquini (UFC) \\ Ana Angélica Lima Gondimii (UESPI)
}

\begin{abstract}
Resumo: O gênero discurso de posse é ainda pouco utilizado na sala de aula da Educação Básica. Ele possui um formato específico, decorrente do seu contexto de produção, que é da esfera política. É marcado pela gratidão aos eleitores e pela promessa de realização dos projetos apresentados durante a campanha pelos candidatos eleitos. Deixam marcas do espaço enunciativo, das vozes, dos posicionamentos e das modalizações quanto aos diferentes conteúdos tratados. Analisamos os discursos de Alzira Soriano (primeira prefeita da América Latina, Lajes/RN), Dilma Rousseff (primeira presidenta da República Federativa do Brasil) e Fátima Bezerra (única mulher eleita para governadora nas últimas eleições). Temos dois objetivos para este artigo: analisar em que o discurso de posse muda no tempo, considerando também a constituição da coerência interativa em cada texto; e apresentar uma proposta de didatização do discurso de posse. Para isso, usamos os estudos das Tradições Discursivas (COSERIU, 1981; KABATEK, 2003) e o Interacionismo Sociodiscursivo (BRONCKART, 2019, 2006, 1999; DOLZ, NOVERRAZ e SCHNEUWLY, 2004), ressaltando a coerência interativa, marcada pelas vozes e pelos posicionamentos e pelas modalizações. Propomos uma intervenção didática (LEUROUIN, 2014, LEUROUIN e BEZERRA, 2020), adaptada da proposta de Cicurel (1991).

Palavras-chave: Discurso de posse; Ensino de leitura; Coerência interativa
\end{abstract}

Resumen: El discurso de asunción todavía se utiliza poco en el aula de Educación Básica. Tiene un formato específico, resultado de su contexto de producción, que es de la esfera política. Está marcado por el agradecimiento a los electores y la promesa de llevar a cabo los proyectos presentados durante la campaña por los candidatos electos. Dejan marcas del espacio enunciativo, de las voces, posicionamientos y modalizaciones respecto a los diferentes contenidos tratados. Analizamos los discursos de Alzira Soriano (primer alcalde de América Latina. Lajes /RN), Dilma Rousseff (primera presidenta de la República Federativa de Brasil) y Fátima Bezerra (única mujer elegida como gobernadora en las últimas elecciones). Tenemos dos 
objetivos para este artículo: analizar cómo el discurso inaugural cambia a lo largo del tiempo, considerando también la constitución de la coherencia interactiva en cada texto; y presentar una propuesta de didáctica del discurso de asunción. Para ello, utilizamos los estudios de Tradiciones Discursivas (COSERIU, 1981; KABATEK, 2003) e Interaccionismo Sociodiscursivo (BRONCKART, 2019, 2006, 1999; DOLZ, NOVERRAZ y SCHNEUWLY, 2004), destacando la coherencia interactiva, marcada por voces, por posicionamiento y por modalizaciones. Proponemos una intervención didáctica (LEUROUIN, 2014, LEURQUIN y BEZERRA, 2020), adaptada de la propuesta de Cicurel (1991).

Palabras-clave: Discurso de asunción; Enseñanza de la lectura; Coherencia interactiva

\section{Introdução}

O ensino de Língua Portuguesa no Brasil tem o texto como centralidade, desde 1998, por orientação dos Parâmetros Curriculares Nacionais (PCN) e essa posição se mantém na Base Nacional Comum Curricular (BNCC, 2017). O grande desafio é como didatizar os gêneros de texto, considerando seus aspectos diversos, inclusive com relação à Tradição Discursiva. Ora, a sociedade muda e as práticas discursivas acompanham a sua evolução, apresentando mudanças externas e internas. No tocante às mudanças internas, observamos que a carta, por exemplo, pode ter sua função cumprida por um e-mail. Quanto às mudanças internas, destacamos aqui alguns pontos: a parte introdutória da carta pessoal - a captação da benevolência mudou (Venho por meio dessas mal traçadas linhas); o e-mail não necessariamente registra a data, o local, o remetente, pois essas informações são desnecessárias tendo em vista o contexto de produção (enviamos o e-mail utilizando o endereço eletrônico do destinatário, a data é desnecessária, pois é registrada no ato do envio).

Todavia, ainda observamos que a carta guarda seu formato geral - vocativo, desenvolvimento do texto, despedida e assinatura. Ressaltamos que a forma de dizer vem sofrendo mudanças a depender dos objetivos, do contexto sócio-histórico e dos posicionamentos, mas o objetivo sociocomunicativo e as características do gênero em questão permanecem. Esse movimento reforça o posicionamento de Bakhtin ao conceituar os gêneros discursivos, que, segundo ele, são "enunciados relativamente estáveis" (BAKHTIN, 1997). O autor faz referência à presença do novo e do velho convivendo e construindo os gêneros. É, então, nesta perspectiva que propomos analisar a constituição dos gêneros. 
Em sua origem, o gênero de texto discurso de posse é escrito para ser oralizado. Nessa ocasião, ele é completado por pausas, entonações, gestos, olhares, vestimentas etc. que contribuem para a construção de sentidos. Essas marcas de oralidade e visuais não são contempladas nas análises que fizemos porque não tivemos acesso ao texto oral nem visual. Os textos foram retirados da imprensa escrita.

Entendemos que a prática de linguagem situada no domínio discursivo da política não pode estar distante do contexto de ensino e aprendizagem da língua materna porque o aluno está completamente inserido nesse domínio discursivo e o espaço de ensino e aprendizagem pode contribuir para a reflexão sobre questões de cunho político. As discussões desenvolvidas e a proposta didática que apresentamos são ancoradas no quadro teórico do Interacionismo Sociodiscursivo (ISD), de acordo com Bronckart (2019, 2006, 1999); Dolz, Noverraz e Schneuwly (2004), alinhadas aos estudos das Tradições Discursivas (TD), com base em Coseriu (1981) e Kabatek (2003). Dentro do quadro do ISD, o texto deve ser analisado em relação ao seu contexto de produção e considerando os níveis que constituem o texto (BRONCKART, 2019, 1999). Assim posicionadas, analisamos a coerência interativa (BRONCKART, 2019; 1999), as vozes, assumidas pelos autores, bem como os posicionamentos feitos, atentando-nos para os traços de agentividade marcados nos discursos.

O nosso objeto de estudo pertence à esfera política, do campo de atuação "vida pública" (BRASIL, 2017). Elegemos os discursos de posse de três mulheres eleitas para cargos nacional, Dilma Rousseff (presidenta); estadual, Fátima Bezerra (governadora); e municipal, Alzira Soriano (prefeita). Essa escolha se deu pela importância delas na História e pelos posicionamentos tomados. São momentos diferentes do Brasil, mas em contextos semelhantes. Nossos objetivos são analisar em que o discurso de posse muda no tempo, considerando também a constituição da coerência interativa em cada texto, e oferecer uma proposta de didatização do discurso de posse. Apresentamos as teorias de base como as lupas para interpretações dos discursos, mostramos os aportes teórico-metodológicos e a proposta de didatização.

\section{Referencial teórico: as lupas para as interpretações das práticas de linguagem}

Como "produtos da atividade humana articulados às necessidades, aos interesses e às condições de funcionamento das formações sociais no seio das quais são produzidos" 
(BRONCKART, 1999, p. 72), o discurso de posse mostra muito do seu contexto social e histórico. Sua concretização textual se dá semioticamente pelo funcionamento engrenado dos níveis que organizam a linguagem: praxiológico, gnosiológico e linguístico. A sua composição se mostra como resultado de escolhas (influenciadas pelo contexto social e pelo objetivo sociocomunicativo) em situação de comunicação. Esta realização se orienta ou se inscreve num modelo de texto, o que Bronckart (1999, p, 75) denomina gênero de texto. A apreensão destes modelos de texto contribui para a produção e a compreensão textuais, pois o gênero funciona como um regulador das diversas possibilidades de interação que os textos empíricos podem assumir.

Pensar o gênero de texto é também entender seus dois níveis: praxiológico e gnosiológico. O primeiro nível está relacionado à produção de textos; é reflexo das práticas sociais coletivas e individuais nas quais o produtor do texto pode atuar, ou seja, os diferentes papeis sociais que ele assume. Já o nível gnosiológico está relacionado aos conhecimentos produzidos pelas gerações anteriores. Percebemos estes dois níveis de organização da linguagem a partir do nível linguístico, na constituição de textos empíricos.

Os textos são gerados a partir das necessidades de determinados campos de atuação (BRASIL, 2017). Essa necessidade de contextualizar as práticas de linguagem é uma das grandes inovações deste documento normatizador da Educação Básica brasileira e está em total consonância com as ideias defendidas tanto pelo ISD quanto pela TD. Conforme Bronckart (2019), para os gêneros serem identificados, devem estar relacionados a dimensões referencial (buscando responder a que atividade o texto deve comentar); a comunicacional (a fim de que se possa compreender para qual interação esse comentário é relevante); e sociocultural (que busca compreender qual é o "valor social adicionado"). O ISD defende a análise de cada texto, em sua individualidade e, para a apreensão do todo textual, propõe a análise do texto em relação a seu contexto de produção, bem como à análise dos seus níveis.

O contexto de produção orienta-se a partir de parâmetros gerados pelas representações dos mundos físico e social que o compõem. O mundo físico engloba o lugar de produção; o momento de produção, a extensão do tempo durante a qual o texto é produzido; o emissor e o receptor correspondem a pessoas físicas que produzem e recebem o texto. Já o mundo social abarca o lugar social; a posição social do emissor (o papel social que o emissor desempenha na interação em curso); a posição social do receptor (o papel 
social atribuído ao receptor do texto); as relações que podem existir entre esses dois tipos de papeis, os valores, as regras, as normas dessa situação e o objetivo (ou objetivos) da interação, além do efeito que o texto pode causar no receptor.

As análises feitas consideram esses parâmetros e a abordagem descendente (VOLOSHINOV ,2006), assumida pelo ISD, na direção que parte das atividades sociais e coletivas para as atividades de linguagem, das atividades para os textos, dos textos para as unidades linguísticas que os constituem, seguindo os três níveis de análises, conforme observamos na Figura 1:

Figura 1: Folhado textual

\begin{tabular}{|l|}
\hline Mecanismos enunciativos (Coerência interativa) \\
Gestão de vozes e Modalizações \\
\hline Mecanismos de textualização (Coerência temática) \\
Conexão e Coesão nominal \\
\hline Infraestrutura geral do texto \\
Organização do conteúdo temático, Tipos de discurso (e as suas modalidades de articulação: encaixe e fusão) \\
e Sequências (e outras formas de planificação) \\
\hline
\end{tabular}

Fonte: Elaborado pelas autoras a partir de Bronckart (2019, 1999)

Com relação ao nível mais superficial, responsável pela coerência interativa (BRONCKART, 2019), temos os mecanismos enunciativos. Estes são constituídos pelas vozes, pelas modalizações e pelo posicionamento enunciativo. A primeira categoria demarca a construção da instância geral de organização do texto, chamada de narrador ou de enunciador, a partir do foco enunciativo. Este foco enunciativo confere a essa instância a responsabilidade pelo conteúdo temático e pode ainda trazer para a cena uma ou várias vozes expressas no texto, que podem ser vozes de personagens, vozes de instâncias sociais e a voz neutra (do próprio autor que produz o texto).

As modalizações (ou atribuições modais) - lógicas ou epistêmicas, deônticas, apreciativas, pragmáticas - traduzem as avaliações do conteúdo temático provenientes de qualquer uma dessas vozes e se realizam através de categorias linguísticas, como advérbios, certos tempos verbais etc. Além delas, que estão relacionadas à mobilização da responsabilidade (capacidade de agir, motivos ou razões), também utilizamos o posicionamento enunciativo a respeito do conteúdo temático para completar o grupo de categorias utilizadas nas análises.

Além do ISD, utilizamos orientações da abordagem Tradições Discursivas, promovendo uma aproximação necessária a partir da compreensão de que os textos se 
constroem nas atividades de linguagem e, dessa forma, são produtos de práticas. Essas são respaldadas em conhecimentos sociossubjetivos e interacionais e estão historicamente ancoradas. O texto deve ser, pois, compreendido em relação ao contexto de produção e histórico no qual foi produzido, mas o contexto de recepção (compreensão) também deve ser considerado, podendo ser entendido como uma unidade de sentido que pode passar por diferentes processos de interpretação no decorrer do tempo.

Nessa direção, consideramos as reflexões levantadas por Coseriu (1981) quanto à apreensão de Tradições Discursivas, quando ele percebe a linguagem dividida em três níveis: 1. O universal, que está relacionado ao falar como uma atividade humana geral, ou seja, conjunto de fenômenos relacionados a todas as línguas; 2 . O nível histórico, que compreende a língua como uma prática histórica que abarca a estrutura linguístico-gramatical, lexical e seu funcionamento; e 3. O individual, que se refere ao texto como uma realização singular e concreta, um ato linguístico (COSERIU, 1981; 2007).

Compreender, então, que cada texto é único, por ser resultado da necessidade de comunicação em uma prática específica não exclui a historicidade relacionada à sua produção e à sua configuração como gênero. Dessa forma, aportamo-nos na concepção de tradições discursivas como o conjunto de características dos gêneros. Conforme Kabatek (2005, p. 32), esta concepção é mais ampla que as concepções de gênero ou texto, pois inclui qualquer tipo de tradições do falar observáveis, ou suborganizações dentro de um mesmo gênero. Nessa perspectiva, analisamos o que permanece (ou não) na constituição do gênero discurso de posse.

Tendo essas teorizações como suporte, apresentamos então uma sugestão de como trabalhar o gênero discurso de posse, com base na proposta na aula interacionista de leitura (LEURQUIN, 2014), adaptada da proposta de Cicurel (1992).

A proposta de Leurquin (2014) compartilha do posicionamento teórico do ISD majoritariamente, mas não exclui o posicionamento das TD. Como nos orienta a pesquisadora, "a aula interacionista de leitura tem como foco o texto, em forma de gênero oral ou escrito, cuja seleção é feita pelo professor, com base em seus objetivos para a aula." (LEUROUIN, 2014, p. 173). Essa proposta didática segue a orientação de uma aula interativa de leitura de Cicurel (1992). Focando a segunda etapa da proposta de Leurquin (2014), após a antecipação, temos a análise a partir dos níveis de texto, como organizada abaixo:

Figura 2: Entradas propostas pela aula interacionista de leitura 
1. Entrada pelo contexto de produção

2. Entrada pelo nível organizacional do texto

3. Entrada pelo nível enunciativo

4. Entrada pelo nível semântico

Fonte: Elaborado pelas autoras a partir de Leurquin (2014)

A aula proposta por Leurquin (2014) tem início na seleção do texto. O segundo momento acontece na sala de aula. Nela, há previstas entradas no texto. A entrada pelo contexto de produção propõe a mobilização dos elementos que constituem este conjunto de parâmetros orientadores; a entrada pelo nível organizacional deve trabalhar os elementos que possibilitam a infraestrutura do texto, bem como dos mecanismos de textualização; a entrada pelo nível enunciativo objetiva a análise dos posicionamentos enunciativos, das vozes e das modalizações; por fim, a entrada pelo nível semântico requer a observação dos tipos de discurso e das figuras de ação. Considerando a proposta deste estudo, nosso foco recai principalmente sobre a entrada pelos mecanismos enunciativos, embora tenhamos apresentado todas elas.

\section{Aportes teórico-metodológicos da pesquisa}

Nossa pesquisa, de natureza documental, analisou um corpus formado por três discursos de posse de três mulheres eleitas para cargos nacional, Dilma Rousseff (presidenta), 2015); estadual, Fátima Bezerra (governadora), 2018; e municipal, Alzira Soriano (prefeita), 1929, como mencionamos anteriormente. Num primeiro momento, a partir do arcabouço teórico do Interacionismo Sociodiscursivo, analisamos cada texto em relação ao contexto de produção e mediante os níveis propostos no folhado textual (com maior foco na observação da coerência interativa). Num segundo momento, observamos os elementos constitutivos do gênero em relação a sua historicidade, considerando a abordagem das Tradições Discursivas. Num terceiro e último momento, apresentamos uma proposta de trabalho didático com o gênero, desenvolvida a partir da proposta da aula interativa de leitura de Leurquin (2014). A fim de contextualizarmos os textos analisados, apresentamos, de maneira sucinta, a trajetória de vida das três autoras, mulheres eleitas para os cargos já mencionados.

A prefeita Luiza Alzira Teixeira Soriano nasceu em Jardim de Angicos, um distrito de Lajes, no Rio Grande do Norte, aos 29 de abril de 1897. Foi uma política brasileira e a primeira 
mulher a ser eleita prefeita de um município na América Latina. Filha mais velha de um influente líder político regional, aos 17 anos de idade, casou-se com um promotor pernambucano, com quem teve três filhas, mas cinco anos após enviuvou quando seu esposo morreu vítima da Gripe Espanhola. Alzira voltou a morar com seus pais em uma fazenda, ficando conhecida por comandar com pulso firme a casa e as atividades da propriedade. Enquanto participava das reuniões promovidas pelo pai, chamou a atenção da líder feminista Bertha Lutz e do político Juvenal Lamartine de Faria, que a convenceram a disputar a prefeitura de Lajes. Durante a campanha eleitoral de 1928, Alzira foi atacada com ofensas misóginas. Entretanto, foi eleita prefeita com mais de 60\% dos votos, assumindo o cargo em 1929. Permaneceu no executivo municipal até a Revolução de 1930 e só voltou a ocupar um cargo público, o de vereadora, em 1947. Após sua morte, recebeu diversas homenagens, incluindo o Diploma Mulher-Cidadã Carlota Pereira de Queirós, outorgado pela Câmara dos Deputados, e um feriado municipal em sua cidade natal.

A presidenta Dilma Vana Rousseff nasceu em Belo Horizonte, aos 14 de dezembro de 1947. É uma economista e política brasileira, filiada ao Partido dos Trabalhadores (PT) e trigésima sexta presidente do Brasil, tendo exercido o cargo de 2011 até seu afastamento por um processo de impeachment em 2016, no seu segundo mandato. Dilma foi membro do Comando de Libertação Nacional (COLINA) e, posteriormente, da Vanguarda Armada Revolucionária Palmares (VAR-Palmares) - ambas as organizações defendiam a luta armada contra a ditadura militar. Passou quase três anos em reclusão, de 1970 a 1972, primeiramente pelos militares da Operação Bandeirante (OBAN), pelos quais foi torturada, e, posteriormente, pelo Departamento de Ordem Política e Social (DOPS). Foi casada com Carlos Araújo (união que durou 30 anos). No Rio Grande do Sul, ajudou a fundar o Partido Democrático Trabalhista (PDT). Durante a gestão do prefeito de Porto Alegre, (1985 a 1988), Alceu Collares, foi secretária municipal da Fazenda; presidente da Fundação de Economia e Estatística e secretária estadual de Minas e Energia (1993 a 1994 e 1999 a 2002). Em 2001 filiou-se ao Partido dos Trabalhadores (PT) e em 2002 participou da equipe que formulou o plano de governo de Luiz Inácio Lula da Silva para a área energética.

Durante o governo Lula, assumiu a chefia do Ministério de Minas e Energia e da Casa Civil. Pelo PT foi a primeira mulher a ser eleita para a presidência do Brasil. Foi reeleita em 2014, e, em 12 de maio de 2016, com o acirramento da crise político-econômica de 2014, foi afastada de seu cargo por até 180 dias devido à instauração de um processo de impeachment 
que vinha sendo movido contra ela, e em agosto de 2016, teve o mandato presidencial definitivamente cassado. Atualmente, este processo de impeachment é interpretado como golpe político, visto que as acusações contra a presidenta não foram comprovadas.

A governadora Maria de Fátima Bezerra nasceu em Nova Palmeira, aos 19 de maio de 1955. É pedagoga e política brasileira, filiada ao Partido dos Trabalhadores (PT); é a atual governadora do Rio Grande do Norte (RN). Formada em Pedagogia pela Universidade Federal do Rio Grande do Norte (UFRN), tornou-se professora da rede pública na prefeitura de Natal e no Estado do RN. Foi ainda vice-presidente (1980-1982) e presidente (1982-1985) da Associação dos Orientadores Educacionais, secretária-geral da Associação dos Professores (1985-1987), secretária-geral (1989-1991) e presidente (1991-1994) do Sindicato dos Trabalhadores em Educação, todos no estado do Rio Grande do Norte.

Os discursos de posse analisados correspondem, respectivamente, ao de posse de Alzira Soriano ${ }^{1}$ (1929) para prefeita, ao do segundo mandato de Dilma Rousseff ${ }^{2}$ para presidenta, em 2015, e ao de Fátima Bezerra3 ${ }^{2}$ (2018) para governadora. Estão disponíveis em sites oficiais do poder executivo de nosso país. Entretanto, como não temos acesso a gravações de áudio ou vídeo destes, mantivemos o foco nos textos escritos. A seguir, apresentamos um quadro com as informações coletadas a partir de nossa análise:

Quadro 1: Categorias do folhado textual que não são o foco desta pesquisa, mas necessárias para a análise

\begin{tabular}{|c|c|c|c|}
\hline & Alzira Soriano (prefeita) & $\begin{array}{ll}\begin{array}{l}\text { Fátima } \\
\text { (governadora) }\end{array} & \text { Bezerra } \\
\end{array}$ & $\begin{array}{l}\text { Dilma Rousseff (presidenta) } \\
2^{\circ} \text { mandato }\end{array}$ \\
\hline Atividade & Agradecimento pela eleição. & $\begin{array}{l}\text { Agradecimento pela } \\
\text { eleição. }\end{array}$ & $\begin{array}{l}\text { Agradecimento pela reeleição, } \\
\text { retomada dos principais feitos } \\
\text { de seu primeiro mandato e } \\
\text { reafirmação das propostas de } \\
\text { campanha. }\end{array}$ \\
\hline $\begin{array}{l}\text { Contexto } \\
\text { sócio- } \\
\text { histórico } \\
\text { amplo }\end{array}$ & $\begin{array}{l}\text { Lajes, RN, Brasil-1929 } \\
\text { Um ano após a vitória do } \\
\text { movimento feminista em prol da } \\
\text { possibilidade de mulheres votarem } \\
\text { e serem votadas. } \\
\text { Primeira prefeita eleita na América } \\
\text { Latina (Partido Republicano). }\end{array}$ & $\begin{array}{l}\text { RN, Brasil- } 2018 \\
\text { Eleição de Bolsonaro como } \\
\text { presidente. } \\
\text { Fátima é eleita pelo Partido } \\
\text { do Trabalhadores (PT), } \\
\text { maior rival político do }\end{array}$ & $\begin{array}{l}\text { Brasília-DF - } 2015 \\
\text { Eleita após seu primeiro } \\
\text { mandato. } \\
\text { Dilma é reeleita pelo Partido } \\
\text { do Trabalhadores (PT). }\end{array}$ \\
\hline
\end{tabular}

\footnotetext{
${ }^{1}$ Disponível em https://lajes.rn.gov.br/especial-alzira-discurso-de-posse/. Acesso em: 01 maio 2021.

${ }^{2}$ Disponível em https://www.camara.leg.br/noticias/448217-integra-do-discurso-de-posse-da-presidentedilma-rousseff-no-congresso/. Acesso em: 01 maio 2021. Justificamos a opção pelo segundo mandato por não termos encontrado o texto completo do primeiro discurso em páginas oficiais. Somos conscientes de que podem aparecer trechos com movimentos que não vão ser encontrados no discurso de posse de um primeiro mandato, e este fato pode ampliar a apreensão deste gênero a partir da compreensão destes novos elementos.

3 Disponível em http://www.tribunadonorte.com.br/noticia/discurso-de-posse-de-fa-tima-bezerra/43469o. Acesso em: 01 maio 2021.
} 


\begin{tabular}{|c|c|c|c|}
\hline & & $\begin{array}{l}\text { presidente Bolsonaro (sem } \\
\text { partido). }\end{array}$ & \\
\hline $\begin{array}{l}\text { Contexto } \\
\text { linguagei } \\
\text { ro } \\
\text { imediato }\end{array}$ & $\begin{array}{l}\text { A prefeita eleita fala para os } \\
\text { cidadãos de Lajes, em 04/01/1929, } \\
\text { no ato da posse. }\end{array}$ & $\begin{array}{l}\text { A governadora eleita para } \\
\text { os cidadãos potiguares, em } \\
\text { 01/01/2018, no ato da } \\
\text { posse. }\end{array}$ & $\begin{array}{l}\text { A presidenta eleita para os } \\
\text { cidadãos brasileiros, em } \\
\text { 01/01/2015, no ato da posse. }\end{array}$ \\
\hline $\begin{array}{l}\text { Conteúdo } \\
\text { temático }\end{array}$ & $\begin{array}{l}\text { Em seu discurso, Alzira menciona o } \\
\text { espaço da mulher na política, sua } \\
\text { eleição como prova de } \\
\text { reconstrução político-social e } \\
\text { iniciativa audaciosa. } \\
\text { O mandato a ser iniciado é } \\
\text { apresentado como uma } \\
\text { experiência difícil. } \\
\text { Justifica sua eleição a partir do } \\
\text { apoio dado pelo movimento liberal } \\
\text { e por suas qualidades enquanto ser } \\
\text { humano. Considerando sua } \\
\text { construção enquanto humana, } \\
\text { assevera que não utilizará o } \\
\text { mandato para tratar de assuntos } \\
\text { pessoais. } \\
\text { Ao final, apresenta Lajes como um } \\
\text { "lar", e seu povo como uma família. }\end{array}$ & $\begin{array}{l}\text { A governadora, em seu } \\
\text { discurso, reflete } \\
\text { inicialmente sobre a } \\
\text { responsabilidade } \\
\text { assumida, agradecendo } \\
\text { aos eleitores pela } \\
\text { confiança. } \\
\text { Enfatiza o contexto social } \\
\text { difícil do RN (retomado } \\
\text { novamente antes de } \\
\text { finalizar sua fala). } \\
\text { Menciona a história da } \\
\text { mulher na política do RN, } \\
\text { Apresenta sua trajetória de } \\
\text { vida pessoal. } \\
\text { Faz promessas coerentes } \\
\text { com o programa de } \\
\text { governo construído no } \\
\text { momento da campanha e } \\
\text { da composição do } \\
\text { secretariado, pasto plano } \\
\text { considerando este } \\
\text { de governo. raça } \\
\text { Por fim, esclarece que } \\
\text { buscará uma relação } \\
\text { coerente com os demais } \\
\text { poderes, e estabelece a } \\
\text { inspiração para sua } \\
\text { atuação em Paulo Freire, }\end{array}$ & 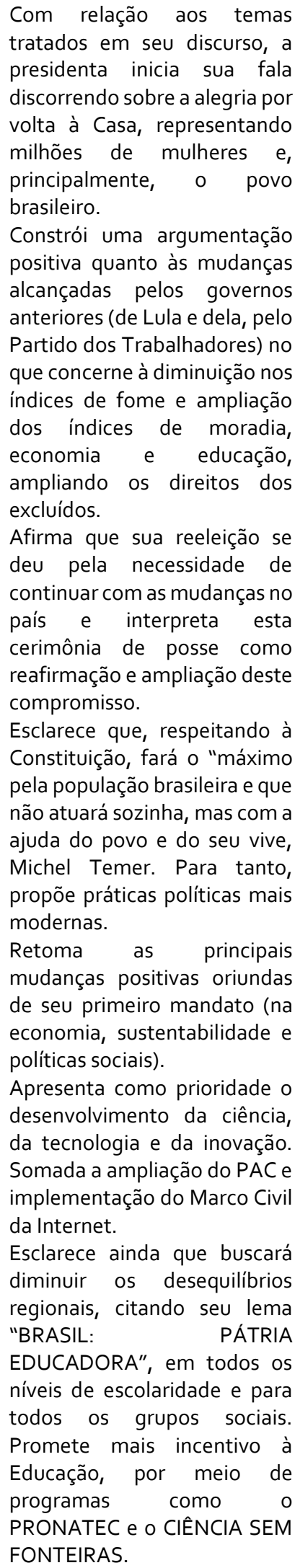 \\
\hline
\end{tabular}




\begin{tabular}{|c|c|c|c|}
\hline & & & $\begin{array}{l}\text { Caminha para o fim de sua fala } \\
\text { fazendo menção à } \\
\text { continuação do Brasil como } \\
\text { líder em políticas sociais, com } \\
\text { a continuação de programas } \\
\text { como o BOLSA FAMÍLIA e o } \\
\text { MINH CASA MINHA VIDA. } \\
\text { Além da criação do programa } \\
\text { MAIS ESPECIALIDADES (na } \\
\text { área da saúde), do } \\
\text { PROGRAMA ESTRATÉGICO } \\
\text { DE FRONTEIRO (contra o } \\
\text { tráfico de drogas) e até } \\
\text { alteração na Constituição } \\
\text { Federal, tornando a segurança } \\
\text { pública uma atividade comum } \\
\text { a todos os entes federados). } \\
\text { A sustentabilidade ambiental } \\
\text { e a ampliação das relações } \\
\text { exteriores são mencionadas, } \\
\text { seguidas penqua } \\
\text { ampliação/fortalecimento da } \\
\text { democracia. } \\
\text { Sua luta contra a corrupção é } \\
\text { tratada no final de seu } \\
\text { discurso, servindo de ensejo } \\
\text { para a proposta de medidas } \\
\text { contra estas práticas. Ainda a } \\
\text { PETROBRÁS é citada como } \\
\text { uma riqueza a ser protegida. } \\
\text { A presidenta resume o que } \\
\text { espera para o país: que ele } \\
\text { deixe de estar "em } \\
\text { desenvolvimento" e passe a } \\
\text { "desenvolvido". } \\
\text { Para finalizar, justifica seu } \\
\text { posicionamentoa partir de sua } \\
\text { trajetória no período da } \\
\text { ditadura como causa de sua } \\
\text { constituição enquanto } \\
\text { brasileira, da formação de seu } \\
\text { coração valente. }\end{array}$ \\
\hline $\begin{array}{l}\text { Plano } \\
\text { global }\end{array}$ & $\begin{array}{l}\text { Comentário sobre o pleito, } \\
\text { relacionando-o ao contexto } \\
\text { político atual; } \\
\text { Descrição de sua trajetória; } \\
\text { (Não) construção de promessas; } \\
\text { Convocação dos cidadãos e Deus } \\
\text { para a realização de seu mandato. }\end{array}$ & $\begin{array}{l}\text { Vocativo (interlocutores); } \\
\text { Comentário sobre o pleito, } \\
\text { relacionando-o que } \\
\text { dificuldades às } \\
\text { encontrará, considerando } \\
\text { o contexto atual do Estado; } \\
\text { Comentário sobre a mulher } \\
\text { na política (com foco no } \\
\text { Estado) } \\
\text { Construção de promessas; } \\
\text { Breve descrição de } \\
\text { trajetória de vida; } \\
\text { Convocação dos cidadãos } \\
\text { potiguares para a } \\
\text { realização de seu mandato. } \\
\text { Um "viva" ao povo } \\
\text { potiguar. }\end{array}$ & $\begin{array}{l}\text { Vocativo (principais líderes } \\
\text { políticos e povo brasileiro); } \\
\text { Comentário sobre o pleito, } \\
\text { relacionando-o ao resultado } \\
\text { positivo alcançado no } \\
\text { mandato anterior; } \\
\text { Comentário sobre as } \\
\text { mudanças já alcançadas; } \\
\text { Construção de promessas; } \\
\text { Repetição } \\
\text { suborganização: desta } \\
\text { Vocativo (relacionado ao povo } \\
\text { brasileiro); } \\
\text { Comentário sobre as } \\
\text { mudanças já alcançadas; } \\
\text { Construção de promessas; } \\
\text { Breve descrição de trajetória } \\
\text { de vida com relação ao período } \\
\text { da Ditadura Militar; } \\
\text { Agradecimento }\end{array}$ \\
\hline
\end{tabular}




\begin{tabular}{|c|c|c|c|}
\hline & & & $\begin{array}{l}\text { Um "Viva o Brasil e viva o povo } \\
\text { brasileiro!" }\end{array}$ \\
\hline $\begin{array}{l}\text { Tipos de } \\
\text { discurso }\end{array}$ & $\begin{array}{l}\text { Discurso interativo (conjunto e } \\
\text { implicado) predominante. } \\
\text { Entretanto, o início do texto "De } \\
\text { outro modo [...] oficina de } \\
\text { trabalho" é construído a partir de } \\
\text { um discurso conjunto e autônomo, } \\
\text { caracterizado como discurso } \\
\text { teórico. }\end{array}$ & $\begin{array}{ll}\text { Discurso } & \text { interativo } \\
\text { (conjunto e implicado) } \\
\text { predominante. }\end{array}$ & $\begin{array}{l}\text { Discurso interativo (conjunto e } \\
\text { implicado) predominante. }\end{array}$ \\
\hline
\end{tabular}

Fonte: Produzido pelas autoras a partir das análises dos discursos de posse das eleitas.

Analisamos a coerência interativa para entendermos posicionamentos enunciativos das autoras com relação ao conteúdo temático construído por elas e elementos constitutivos do gênero discurso de posse em relação a sua historicidade, considerando a abordagem das Tradições Discursivas. Por fim, apresentamos uma proposta de trabalho didático com o gênero, desenvolvida a partir da proposta da aula interativa de leitura de Leurquin (2014).

\section{As vozes em cena nos discursos}

As vozes das autoras são substituídas por uma instância geral de enunciação representada pelo expositor. No discurso de Alzira Soriano, há um entrelace da voz que, de forma quase total, é a instância geral de enunciação que assume a responsabilidade do dizer. Entretanto, em alguns casos, esta instância de enunciação também põe em cena a voz social, que remete ao machismo no trecho "esta doce colaboradora do lar". Esta caracterização relacionada à mulher é trazida pela prefeita para ser desconstruída, visto que ela assumira uma função divergente desta. Alzira Soriano se remete à voz do machismo para negá-lo, coerente com a orientação e o acompanhamento que vinha recebendo do movimento feminismo à época.

Já no discurso de Fátima Bezerra, a instância geral de enunciação assume a responsabilidade do dizer. Uma característica que se destaca na apresentação desta voz é a marcação da primeira pessoa do singular (eu) representando Fátima como candidata e a marcação da primeira pessoa do plural (nós) representando Fátima eleita ao cargo de governadora. Interpretamos esta diferenciação como a marcação de alguém que conseguiu a eleição de forma mais independente, mas que se propõe a governar como representante de um grupo, a partir das convicções e planejamentos deste grupo que entendemos ser o partido político ao que está filiada, o Partido dos Trabalhadores.

Em relação ao discurso de Dilma Rousseff, observamos também a predominância da instância geral de enunciação que assume a responsabilidade do dizer. Entretanto, em alguns 
momentos, esta instância de enunciação põe em cena outras vozes que assumem a responsabilidade pelo que está sendo dito. Percebemos a presença de uma voz social que remete ao Partido dos Trabalhadores, pois são enumeradas ações realizadas por um "nós" que correspondem a ações realizadas durante o primeiro mandato da presidenta, bem como aos mandatos do presidente Luís Inácio Lula da Silva.

Mas também há a presença de uma voz de personagem colocada em cena, é a construída no jingle da campanha, que apresenta Dilma como "coração valente", o que é utilizado pela expositora para assumir a imagem construída durante o mandato anterior, principalmente, durante a campanha. A voz de personagem aparece no trecho "O impossível se faz já; só os milagres ficam para depois". Colocada em jogo como representando a chave para vencer todas as dificuldades em seu governo, o verso é citado, mas sua autoria não é mencionada, nem por nós foi identificada. Entretanto é esta voz que arrebata com tom de profecia o discurso da presidenta.

Ao identificar e compreender a construção das vozes a partir dos pronomes ou flexões verbais, podemos entender a responsabilidade enunciativa atrelada às vozes, bem como o engajamento ou não da instância principal. Isso nos permite ensinar a construção da criticidade a respeito desta responsabilidade, visto que podemos perceber a compreensão desta voz de forma mais individual ou coletiva, trazendo vozes para negá-las ou assumi-las, dentre outros movimentos de leitura crítica que podemos realizar.

\section{As modalizações e a construção de avaliações dos conteúdos temáticos}

No tocante às modalizações do discurso de Alzira Soriano, observamos muito marcadamente modalizações apreciativa, devido à opção que ela fez ao falar a primeira vez para a população, como vemos a seguir:

Excerto 1: Determinaram os acontecimentos sociais do nosso querido Rio Grande do Norte na sua constante evolução da democracia, que a mulher, esta doce colaboradora do lar, se voltasse também para colaborar com outra feição na sua obra político-administrativa. De outro modo, portanto, não poderia ser. (SORIANO, 1929)

A modalização apreciativa positiva marcada pelo uso dos adjetivos "querido" e "doce" para se referir ao Estado e a ela própria, mostra um tom de acolhimento e união, seguida pelo uso da modalização deôntica representada por "não poderia ser", que funciona como suporte positivo para valorizar os resultados das eleições e suas características. No trecho que segue, a modalização deôntica, construída pela mesma estrutura linguística (partícula de negação e 
perífrase verbal), marca um posicionamento sobre sua eleição, mostrando não poder ser considerada apenas inovação estética, mas sim fruto de uma conquista:

Excerto 2: As conquistas atuais, a evolução que ora se opera, abrem uma clareira no convencionalismo, fazendo ressurgir a nova faceta dos sagrados direitos da mulher. Inovação estética não pode ser, o que se observa é a consciência elegante de uma conquista. (SORIANO, 1929)

As marcas de modalização apreciativas são frequentes em seu discurso, mas a prefeita constrói um jogo discursivo interessante quando também utiliza modalização lógica como podemos observar neste momento de sua fala: "[...] não ouso fazer promessa que a minha incapacidade e talvez a insuficiência dos estímulos necessários me poderiam privar de cumprir". O advérbio de dúvida "talvez" apresenta a avaliação quanto à "insuficiência dos estímulos necessários" somados à incapacidade da eleita para a não realização de promessas. Alzira compreende as possibilidades (ou não) do mundo objetivo para a realização de ações após eleição, e assim a prefeita opta por não construir promessas em seu discurso de posse.

No trecho mais adiante, observamos um conjunto de modalizações (deôntica, apreciativa e lógicas), utilizadas para fortalecer o argumento construído pela prefeita informar ao público que não manterá promessas. A utilização do verbo "poder" relaciona-se ao que, considerando as regras sociais, ela buscará realizar; o "querer" reflete a avaliação vinda de seu mundo subjetivo para apontar que não citaria projetos que novamente não são colocados como possibilidade a partir da utilização do advérbio "talvez". Este julgamento é reforçado pela utilização do advérbio "jamais" para negar qualquer possibilidade de buscar vantagens nesta função.

Excerto 3: É porque, sem prejuízo da natural modéstia, posso assegurar-vos ao menos o esforço veemente para não desmerecer, quero apenas, seguindo um grande exemplo da história política nacional, registrar o que não farei no exercício do mandato, de preferência a alinhar projetos, que talvez não pudesse realizar. Não me prevalecerei do cargo para fazer favores a amigos e ainda menos para negar justiça a adversários. Não abusarei dele para obter provento seja qual for a natureza destes. O infortúnio do meu estado civil ensinou-me a trabalhar e a viver modestamente com honra, e não trocarei jamais a clama da consciência e altivez da mediania por vantagens mais ou menos suspeitas que pudesse auferir da função pública. (SORIANO, 1929)

Por fim, registramos a que grupo social ela se remete em seu discurso e como ela o modaliza ao selecionar o verbo "dever": "A família tem um jardim, sala, gabinete de trabalho, mesa, despensa e tudo se deve equilibrar sobre a pauta rigorosa dos ganhos e das despesas". Essa modalização deôntica se refere ao equilíbrio necessário entre ganhos e despesas. 
Em relação ao discurso de Fátima Bezerra, as modalizações são, predominantemente, deônticas, entretanto é possível observar a presença de uma modalização lógica no início do texto, com relação à responsabilidade assumida com a investidura no cargo "Assumo, sem dúvida nenhuma, a tarefa mais desafiadora da minha vida política: ser governadora do estado do Rio Grande do Norte". Além de assumir a agentividade no seu discurso, trazendo para si a responsabilidade, a locução adverbial "sem dúvida" utiliza as ordenadas do mundo ordinário para construir a certeza de que não há tarefa mais desafiadora para Fátima até então.

O jogo discursivo marcado pela fala da governadora, ao pedir apoio da população, constrói-se, sobretudo, no uso dos modalizadores "poder", "precisar" e "dever", conforme observamos:

Excerto 4: Da humildade de quem sabe que não se pode governar sozinha"; "Essa situação, que se tornou rotineira, não pode ser, por nós, naturalizada"; "Precisamos superar gradativamente a crise fiscal em que o RN se encontra; regularizar o pagamento dos servidores públicos" e "A população disse que esse Estado não tem mais donos e que mesmo na adversidade nós devemos ter esperança. (BEZERRA, 2018)

A utilização da partícula de negação junto ao verbo "poder", bem como a utilização dos verbos "precisar" e "dever" remetem a uma obrigatoriedade, construída socialmente e esta é uma marca constante no discurso de Fátima Bezerra.

Já no discurso de Dilma Rousseff, há um eco que se forma no uso da modalização lógica "nunca", reforçando o pioneirismo de sua gestão, de governos do Partido dos Trabalhadores:

Excerto 5: Nunca tantos brasileiros ascenderam às classes médias; nunca tantos brasileiros conquistaram tantos empregos com carteira assinada; nunca o salário mínimo e os demais salários se valorizaram por tanto tempo e com tanto vigor, nunca tantos brasileiros se tornaram donos de suas próprias casas; nunca tantos brasileiros tiveram acesso ao ensino técnico e à universidade; nunca o Brasil viveu um período tão longo sem crises institucionais; nunca as instituições foram tão fortalecidas e respeitadas e nunca se apurou e puniu com tanta transparência a corrupção. (ROUSSEFF, 2015)

O uso do advérbio de negação "nunca" constrói uma afirmação e várias reafirmações (enfáticas) da impossibilidade de outros governos terem feito tanta diferença com relação aos distintos aspectos mencionados, a partir das orientações do mundo ordinário.

O uso das modalizações deônticas aconteceu para mostrar a obrigação de se respeitar as necessidades básicas do povo, como observamos em "Em nossos governos, cumprimos o compromisso fundamental de oferecer a uma população enorme de excluídos, de pessoas 
excluídas, os direitos básicos que devem ser assegurados a qualquer cidadão". A perífrase verbal "dever ser" relaciona-se às ações a serem realizadas em prol do respeito aos direitos dos cidadãos, conforme as normas sociais. Já em "Sim, neste momento, ao invés de simplesmente garantir o mínimo necessário, como foi o caso ao longo da nossa história, temos, agora, que lutar para oferecer o máximo possível". A perífrase verbal "ter que lutar" representa um chamamento e é utilizada para ampliar a obrigação já assumida.

A modalização pragmática "querer" é bastante marcada concernente à capacidade de agir da população brasileira e aos seus anseios: "A população quis que ficássemos porque viu o resultado do nosso trabalho, compreendeu as limitações que o tempo nos impôs e concluiu que podemos fazer muito mais" e "O povo brasileiro quer mudanças, quer avançar e quer mais", ou em "O povo brasileiro quer democratizar, cada vez mais, a renda, o conhecimento e o poder. O povo brasileiro quer educação, saúde, e segurança de mais qualidade. O povo brasileiro quer ainda mais transparência e mais combate a todos os tipos de crimes, especialmente a corrupção e quer ainda que o braço forte da justiça alcance a todos de forma igualitária", apresentando coerência entre o que o povo deseja e as propostas de Dilma, construindo um motivo para sua reeleição.

Quanto ao conteúdo temático principal, observamos que Alzira Soriano apresenta um posicionamento favorável sobre o cargo para o qual foi eleita, bem como quanto ao contexto que possibilitou tal concretização. Fátima Bezerra, de maneira geral, constrói um posicionamento favorável quanto ao cargo para o qual foi eleita, entretanto é possível observar um posicionamento desfavorável quanto à responsabilidade assumida, considerando o "difícil" contexto no qual o Estado se encontra. Já a presidenta Dilma Rousseff reflete um posicionamento favorável quanto ao cargo para o qual foi eleita, quanto ao mandato anterior e quanto à continuidade das ações a serem implementadas.

\section{Historicidade do gênero discurso de posse}

Há um breve espaço temporal que de oitenta e nove anos entre os discursos. Mesmo assim, constatamos transformações que apresentamos no quadro que segue, embora a função de agradecer a eleição seja comum a todas, além de assumir, publicamente, as responsabilidades relacionadas ao cargo para o qual houve a eleição, conforme vemos no quadro que segue

Quadro 2: Historicidade do gênero discurso de posse 


\begin{tabular}{|c|c|c|}
\hline Alzira Soriano & Fátima Bezerra & Dilma Rousseff \\
\hline 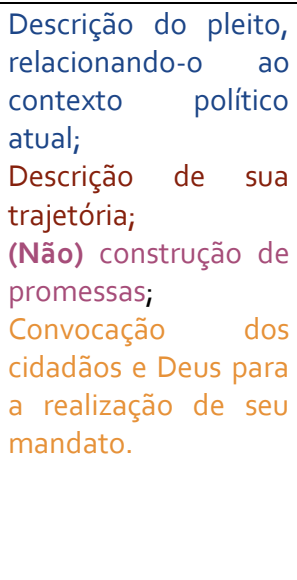 & $\begin{array}{l}\text { Vocativo (interlocutores); } \\
\text { Descrição do pleito, relacionando-o } \\
\text { às dificuldades que encontrará, } \\
\text { considerando o contexto atual do } \\
\text { Estado; } \\
\text { Descrição da situação da mulher na } \\
\text { política (com foco no Estado) } \\
\text { Construção de promessas; } \\
\text { Breve descrição de trajetória de } \\
\text { vida; } \\
\text { Convocação dos cidadãos } \\
\text { potiguares para a realização de seu } \\
\text { mandato. } \\
\text { Um "viva" ao povo potiguar. }\end{array}$ & $\begin{array}{l}\text { Vocativo (principais líderes políticos e povo brasileiro); } \\
\text { Descrição do pleito, relacionando-o ao resultado } \\
\text { positivo alcançado no mandato anterior; } \\
\text { Descrição das mudanças realizadas pelo partido e por } \\
\text { seu governo anterior; } \\
\text { Construção de promessas; } \\
\text { Repetição desta suborganização: } \\
\text { Vocativo (relacionado ao povo brasileiro); } \\
\text { Descrição das mudanças realizadas pelo partido e por } \\
\text { seu governo anterior; } \\
\text { Construção de promessas; } \\
\text { Breve descrição de trajetória de vida com relação ao } \\
\text { período da Ditadura Militar; } \\
\text { Agradecimento } \\
\text { Um "Viva o Brasil e viva o povo brasileiro!" }\end{array}$ \\
\hline
\end{tabular}

Fonte: produzido pelas autoras a partir da organização dos discursos analisados.

Os discursos de posse são iniciados por vocativos, devido ao contexto de produção, os vencedores dos pleitos agradecem a seus eleitores e apoiadores. Duas hipóteses para que o discurso da prefeita Alzira Soriano (1929) não seja iniciado por vocativo como os demais: a) ou no período em que foi escrito não existia a prática de apenas ler o discurso de posse, o que faria com que este documento servisse como um orientador da fala real, ou b) na esfera municipal os discursos de posse não seriam produzidos com tanto rigor, podendo, inclusive, serem construídos de forma criativa, sem uma preparação anterior.

Há uma descrição geral sobre o pleito, relacionando-a ao contexto sócio-histórico da esfera política (municipal, estadual ou federal), podendo especificar relações negativas como quando Fátima Bezerra menciona a difícil situação do estado do RN, ou positivo quando Dilma Rousseff elenca as ações positivas realizadas em governos anteriores.

No discurso da prefeita, há também a descrição de sua trajetória; Bezerra inicia sua fala pela situação da mulher na política (com foco no Estado); e uma descrição das mudanças geradas pelo governo do PT pela então presidenta. Em seu discurso, Rousseff repete vários vocativos, descrições das mudanças já alcançadas por seu governo ou pelo governo do Partido dos Trabalhadores de modo geral, o que atribuímos à extensão deste discurso.

A governadora e a presidenta eleitas ainda constroem promessas, antes da apresentação de suas respectivas trajetórias, contrariamente à prefeita que diz que "não" construirá promessas, ainda que acabe construindo-as, quando menciona que não tirará proveito do cargo para benefício próprio ou de outrem que não seja para a população de Lajes como um todo. Após estes movimentos, a prefeita e a governadora convocam os cidadãos para a construção de um mandato democrático; a primeira convoca Deus para auxiliá-la na 
função assumida, já a segunda não realiza textualmente esta convocação. Ao final, governadora e presidenta saúdam os interlocutores, população potiguar e o povo brasileiro respectivamente, com um "viva". Movimento não realizado, pelo menos textualmente, pela prefeita. O discurso da governadora se remete ao contexto da mulher da política, nos outros dois, o tópico é mencionado, mas bem menos desenvolvido.

Podemos constatar a permanência do objetivo sociocomunicativo de agradecer aos eleitores e apoiadores e reafirmar as propostas e posicionamentos construídos anteriormente ao pleito. Com relação à estrutura, vimos trechos que possuem a mesma função: Vocativo (interlocutores); descrição do pleito; construção de promessas; breve descrição de trajetória de vida (seja pessoal, profissional ou política); convocação dos cidadãos para a realização de seu mandato; e um "viva" aos cidadãos que serão que constituem as respectivas esferas. Estes segmentos acontecem predominantemente e podem localizar-se de forma diferente dentro do texto, podem ser construídos de maneira mais ou menos detalhada. Na seção a seguir apresentamos uma proposta didática de trabalho com o gênero discurso de posse a partir do corpus analisado.

Mas, é preciso também remarcar a ampliação no tocante ao compromisso assumido pelas políticas, o que representa uma mudança na postura assumida no discurso porque há um maior compromisso político. Isso também traz em evidência o papel assumido por cada uma no contexto político no qual está envolvida.

\section{O gênero discurso de posse na sala de aula de Língua Portuguesa}

A proposta didática que segue tem como foco a aula interacionista de leitura de Leurquin (2014) e, a partir da adequação da linguagem, dos objetivos e habilidades e coerente com o campo de atuação propostos pela BNCC, pode ser utilizada no Ensino Médio.

Quadro 3 - Proposta didática para o ensino do gênero discurso de posse a partir da aula interativa de leitura

I- Quanto às contexto de produção

1. Considerando a leitura feita do discurso de posse de Alzira Soriano (1929), Fátima Bezerra (2018) e Dilma Rousseff (2015):

a) Quem são Alzira Soriano, Fátima Bezerra e Dilma Rousseff, o que elas têm em comum e os que as diferenciam? Como elas se representam nos discursos?

b) Para quem cada discurso foi direcionado? Com qual objetivo?

c) Considerando que Alzira Soriano foi a primeira prefeita eleita na América Latina, Dilma Rousseff a primeira presidenta do País e Fátima Bezerra a única mulher eleita para governadora nas eleições de 2018, qual a importância da eleição de cada uma para estes contextos sócio-históricos?

II- Quanto ao nível organizacional

1. Ao construir os discursos, cada candidata eleita trata de diferentes conteúdos temáticos. Alzira Soriano trata I) 
do espaço da mulher na política, II) o mandato como uma experiência difícil, III) do apoio do movimento liberal e de suas qualidades humanas e IV) da cidade Lajes como um "lar", e seu povo como uma família. Já Fátima Bezerra I) reflete inicialmente sobre a responsabilidade assumida, agradecendo aos eleitores pela confiança, II) enfatiza o contexto social difícil do RN, III) menciona a história da mulher na política do Rio Grande do Norte, IV) apresenta sua trajetória de vida pessoal, $V$ ) faz promessas coerentes com o programa de governo construído no momento da campanha e VI) esclarece que buscará uma relação coerente com os demais poderes, inspirada ne perspectiva de Paulo Freire.

a) Em quais trechos, elas se implicam ou não em seus discursos?

b) Como percebe e entende essas implicações?

c) Com relação aos tempos verbais, quando elas os utilizam o que predomina em seu discurso (tempos no presente, no passado ou no futuro)? Há uma relação entre o objetivo dos diferentes trechos? Por exemplo, ao mencionar trajetória, ao agradecer, ao descrever o pleito, ao construir promessas, quais tempos verbais são utilizados?

2. Considerando a leitura dos discursos anteriores, Fátima Bezerra (2018), de Dilma Rousseff (2015) e de Alzira Soriano (1929), o que permanece nos três discursos que nos asseguram estar diante de um mesmo gênero de texto, discurso de posse?

3. Tendo como base o discurso de Alzira Soriano, percebemos que a prefeita eleita faz um plano que nos permite perceber uma progressão, diferentes conteúdos temáticos são tratados e interrelacionados A partir desses conhecimentos, elabore um resumo de seu discurso, considerando o que a prefeita constrói em seu discurso de posse (agradecimento, trajetória, descrição do pleito etc.).

4. Muitas vezes, Alzira se remete à figura da mulher na sociedade. Faça o levantamento das retomadas, identifique os elementos linguístico-discursivos que assumem esta função e interprete que sentidos podemos atribuir a partir da coesão nominal neste discurso de posse.

\section{III- Quanto ao nível enunciativo}

1. Considerando que algumas expressões podem representar avaliações que fazemos quanto ao conteúdo temático, leia o trecho que segue do discurso de Alzira Soriano: "A família tem um jardim, sala, gabinete de trabalho, mesa, despensa e tudo se deve equilibrar sobre a pauta rigorosa dos ganhos e das despesas" (SORIANO, 1929).

a) Quando pensamos no sentido da expressão em destaque, a que tipo de julgamento (físico, social ou pessoal/subjetivo) ela nos remete e que efeitos podemos observar na compreensão do discurso de Alzira Soriano?

b) Que outras expressões podem ser observadas com este mesmo valor no texto da prefeita de Lajes?

2. Com relação ao discurso de Fátima Bezerra, observamos que a voz da autora assume a responsabilidade do dizer. Uma característica que se sobressai na apresentação desta voz é a marcação da primeira pessoa do singular representando Fátima como candidata e a marcação da primeira pessoa do plural representando Fátima eleita. Como podemos interpretar esta alternância em que não deixa de haver implicação, mas que ela se configura de maneira distinta?

3. Em um dos trechos do discurso da presidenta Dilma Rousseff sobre as mudanças vivenciadas pelo povo brasileiro a partir da assunção do governo do Partido dos Trabalhadores ao poder, ela afirma "Nunca tantos brasileiros ascenderam às classes médias. Nunca tantos brasileiros conquistaram tantos empregos com carteira assinada. Nunca o salário mínimo e os demais salários se valorizaram por tanto tempo e com tanto vigor. Nunca tantos brasileiros se tornaram donos de suas próprias casas. Nunca tantos brasileiros tiveram acesso ao ensino técnico e à universidade. Nunca o Brasil viveu um período tão longo sem crises institucionais. Nunca as instituições foram tão fortalecidas e respeitadas e nunca se apurou e puniu com tanta transparência a corrupção" (ROUSSEFF, 2015). O que a utilização deste advérbio de tempo, repetidamente utilizado, representa no trecho em destaque?

4. Qual o posicionamento das eleitas sobre o momento que estão vivenciando (a eleição) e o futuro (o mandato)?

\section{IV- Quanto ao nível semântico}

1. No discurso de Alzira Soriano, a autora nos diz que "Determinaram os acontecimentos sociais do nosso querido Rio Grande do Norte na sua constante evolução da democracia, que a mulher, esta doce colaboradora do lar, se voltasse também para colaborar com outra feição na sua obra político-administrativa" (SORIANO, 1929). Qual a compreensão do papel da mulher na sociedade a partir da expressão de destaque?

2. Finalizando seu discurso, Dilma Rousseff reflete sobre si "Deus colocou em meu peito um coração cheio de amor pela minha pátria. Antes de tudo, o que a música cantava, um coração valente, não é que a gente não tem medo de nada, a gente controla o medo. Um coração que dispara no peito com a energia do amor, do sonho e, sobretudo, com a possibilidade de construir um Brasil desenvolvido. Eu não tenho medo de proclamar para vocês que nós vamos vencer todas as dificuldades, porque temos a chave para vencê-las, vencer todas as dificuldades" (ROUSSEFF, 2015). Qual a representação que temos de "Dilma coração valente"?

Para ir mais além: 
- Você deve selecionar uma das políticas que ainda estão vivas, Dilma Rousseff ou Fátima Bezerra, e entrevistá-la. Quais perguntas gostaria de fazer sobre os mandatos? Depois socialize com os colegas da turma.

-Se você assumisse o papel que uma delas assumiu, como poderia melhorar a vida do povo?

Nota: O material poderá servir a um possível projeto de letramento que esteja sendo desenvolvido na escola.

Fonte: Elaborado pelas autoras.

Há muito a trabalhar a partir dos discursos de posses das três importantes brasileiras. Mas foi preciso fazer opções. Como mencionamos anteriormente, demos maior foco à coerência interativa construída em cada discurso, sem perder de vista o contexto de produção e os demais níveis de organização do folhado textual.

\section{Considerações finais}

A configuração linguística dos textos é resultado de escolhas de nível macro (escolha do modelo de texto a ser seguido) ao micro (escolhas lexicais e organização de enunciados). Ao construir representações do contexto de produção, bem como de elementos que permitem a apreensão da responsabilidade enunciativa com o que está sendo dito, podemos apreender a representação que os autores fazem de si e dos conteúdos temáticos tratados.

A partir de nossa análise, identificamos que o gênero discurso de posse continua com o objetivo sociocomunicativo "de agradecer a vitória no pleito" aos apoiadores e eleitores, reiterar o merecimento da vitória, apresentar a trajetória do eleito e reafirmar promessas feitas. A estrutura não sofre significativas mudanças internas. Há segmentos que se repetem, além dos acima mencionados; há a convocação dos cidadãos para a realização de seu mandato (discursos de Soriano e Bezerra); e o uso de vocativos e um "viva" aos cidadãos que serão que constituem as respectivas esferas (discursos da governadora e da presidenta).

Há predominância da voz da instância geral de enunciação de expositor (visto que o discurso interativo impera nos três textos); modalizações de diferentes ordens, com maior foco em modalizações deônticas, de cunho social, coerente com a função social assumida. As avaliações são, predominantemente, feitas a partir das normas sociais. Há posicionamentos positivos das eleitas; seu papel também avaliado, ainda que não suficiente. As construções textuais se relacionam aos contextos sociais e do próprio gênero, mas as operações são influenciadas pelo produtor, do texto, responsável pela construção textual e que se traduz na presença ou ausência de determinadas marcas linguísticas mobilizadas 
A proposta didática focaliza a formação de um leitor crítico, capaz de compreender o modelo de gênero, bem como os elementos que o constituem como tal, a individualidade de cada texto configurado neste modelo de texto, a permanência (ou não) de segmentos que os constituem e a coerência interativa que nos permite perceber como as autoras se representam e como representam os conteúdos tratados no texto.

\section{Referências bibliográficas}

BAKHTIN, Mikhail. Os gêneros do discurso. In: Estética da criação verbal. 2' cd. -São Paulo Martins Fontes, 1997. P. 277-326.

BRONCKART, Jean-Paul. Atividade de linguagem, textos e discursos. Por um interacionismo sociodiscursivo. 2. ed. São Paulo: EDUC, 2009[1999].

BRONCKART, Jean-Paul. Théories du langage: nouvelle introduction critique. Bruxeles: Mardaga, 2019.

CICUREL, Francine. Lecture interatives en langue étrangère. Paris, Hachette, 1991.

COSERIU, Eugênio. Lecciones de lingüistica general. Madrid: Gredos, 1981.

DOLZ, Joaquim; NOVERRAZ, Michele; SCHNEUWLY, Bernard. Sequências didáticas para o oral e a escrita: apresentação de um procedimento. In: SCHNEUWLY, Bernard; DOLZ, Joaquim. Gêneros orais e escritos na escola. Tradução de Roxane Rojo e Glaís Sales Cordeiro. Campinas, SP: Mercado das Letras, 2004, p. 95-128.

KABATEK, Johannes. Tradiciones Discursivas y Cambio Lingüístico. Fundacion Duques de Soria. Seminário de História da Língua Espanhola "El cambio lingüístico na historia española. Nuevas perspectivas". Soria, Del 7 a 11 de Julio de 2003.

LEURQUIN, Eulália Vera Lúcia Fraga. O espaço da leitura e da escrita em situações de ensino e aprendizagem de Português língua estrangeira. Pernambuco. Revista Eutomia, Revista de Literatura e Linguística, p. 167-187, dez. 2014.

LEUROUIN, Eulália Vera Lúcia Fraga; BEZERRA, Renata Uchoa. A leitura de fábulas na perspectiva do Interacionismo Sociodiscursivo. Leitura, Maceió, n. 67, set./dez. 2020, Dossiê Linguística Aplicada, p. 83-98.

SOUZA, Karina Maria da Silva. Poderes e progressos: as relações que constituíram a candidatura de Alzira Soriano. Lajes: Cactus Editora, 2021.

\footnotetext{
i Doutora em Educação. Professora Associada da Universidade Federal do Ceará.

E-mail: eulaliaufc@gmail.com

ii Doutora em Linguística. Professora Assistente da Universidade Estadual do Piauí.

E-mail: gondimufc@gmail.com
} 